European Construction 
Macmillan Building and Surveying Series

Series Editor: Ivor H. Seeley

Emeritus Professor, Nottingham Trent University

Advanced Building Measurement, second edition Ivor H. Seeley

Advanced Valuation Diane Butler and David Richmond

Applied Valuation Diane Butler

Asset Valuation Michael Rayner

Building Economics, third edition Ivor $\mathrm{H}$. Seeley

Building Maintenance, second edition Ivor H. Seeley

Building Maintenance Technology Lee How Son and George C.S. Yuen

Building Procurement Alan E. Turner

Building Project Appraisal Keith Hutchinson

Building Quantities Explained, fourth edition Ivor H. Seeley

Building Surveys, Reports and Dilapidations Ivor H.Seeley

Building Technology, fifth edition Ivor H. Seeley

Civil Engineering Contract Administration and Control, second edition Ivor H. Seeley

Civil Engineering Quantities, fifth edition Ivor H. Seeley

Civil Engineering Specification, second edition Ivor H. Seeley

Commercial Lease Renewals - A Practical Guide Philip Freedman and Eric F. Shapiro

Computers and Quantity Surveyors A.J. Smith

Conflicts in Construction - Avoiding, managing, resolving Jeff Whitfield

Construction Contract Claims Reg Thomas

Construction Law Michael F. James

Contract Planning and Contract Procedures, third edition B. Cooke

Contract Planning Case Studies B. Cooke

Cost Estimates of Structures in Commercial Buildings Surinder Singh

Design-Build Explained D.E.L. Janssens

Development Site Evaluation N.P. Taylor

Environment Management in Construction Alan Griffith

Environmental Science in Building, third edition R. McMullan

European Construction - Procedures and techniques B. Cooke and G. Walker

Facilities Management Alan Park

Greener Buildings - Environmental impact of property Stuart Johnson

Housing Associations Helen Cope

Housing Management - Changing Practice Christine Davies (Editor)

Information and Technology Applications in Commercial Property Rosemary Feenan and Tim Dixon (Editors)

Introduction to Building Services, second edition Christopher A. Howard and Eric F. Curd

Introduction to Valuation, third edition D. Richmond

Marketing and Property People Owen Bevan

Principles of Property Investment and Pricing, second edition W.D. Fraser

Project Management and Control David Day

Property Valuation Techniques David Isaac and Terry Steley

Public Works Engineering Ivor H. Seeley

Resource Management for Construction M.R. Canter

Quality Assurance in Building Alan Griffith

Quantity Surveying Practice Ivor H. Seeley

Recreation Planning and Development Neil Ravenscroft

Resource and Cost Control in Building Mike Canter

Small Building Works Management Alan Griffith

Structural Detailing, second edition P. Newton

Urban Land Economics and Public Policy, fourth edition P.N. Balchin, J.L. Kieve and G.H. Bull

Urban Renewal - Theory and Practice Chris Couch

1980 JCT Standard Form of Building Contract, second edition R.F. Fellows 


\title{
European Construction
}

\section{Procedures and techniques}

\author{
B. Cooke \\ Principal Lecturer in Construction Management \\ Liverpool John Moores University \\ G. Walker \\ Senior Lecturer in Building Technology \\ Bolton Institute
}

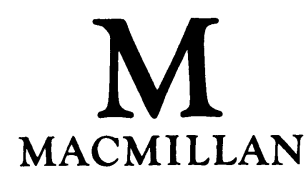


() B. Cooke and G. Walker 1994

All rights reserved. No reproduction, copy or transmission of this publication may be made without written permission.

No paragraph of this publication may be reproduced, copied or transmitted save with written permission or in accordance with the provisions of the Copyright, Designs and Patents Act 1988, or under the terms of any licence permitting limited copying issued by the Copyright Licensing Agency, 90 Tottenham Court Road, London W1P 9HE.

Any person who does any unauthorised act in relation to this publication may be liable to criminal prosecution and civil claims for damages.

First published 1994 by

THE MACMILLAN PRESS LTD

Houndmills, Basingstoke, Hampshire RG21 2XS

and London

Companies and representatives

throughout the world

ISBN 978-0-333-59465-0

ISBN 978-1-349-13218-8 (eBook)

DOI 10.1007/978-1-349-13218-8

A catalogue record for this book is available from the British Library

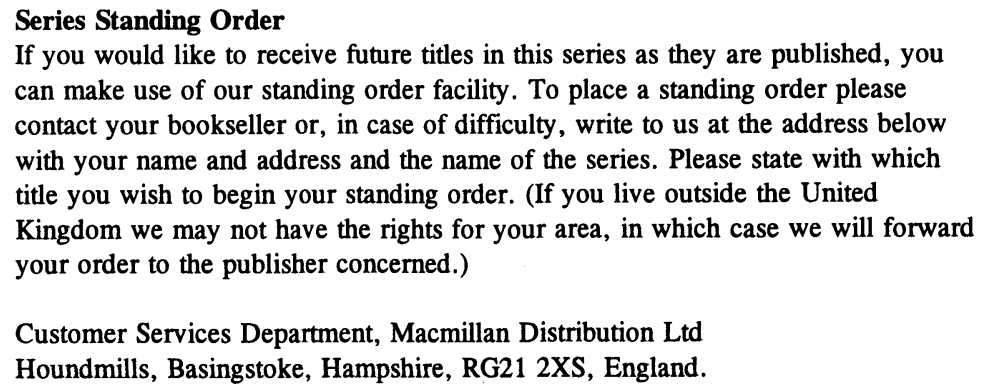




\section{Contents}

Preface vii

Acknowledgements viii

1 Introduction to the European Union 1

2 The Construction Industry in Denmark 18

2.1 Key information $\quad 18$

2.2 Construction output $\quad 18$

2.3 Review of the construction industry 19

2.4 Extent of regionalisation $\quad 21$

$\begin{array}{ll}2.5 \text { The housebuilding industry } & 21\end{array}$

$\begin{array}{ll}2.6 \text { Relationships within the construction industry } & 24\end{array}$

2.7 Role of the architect $\quad 24$

2.8 Role of the engineer $\quad 26$

2.9 Role of the quantity surveyor $\quad 28$

2.10 Contractual arrangements and building procurement 29

$\begin{array}{ll}2.11 \text { Planning and building control procedures } & 33\end{array}$

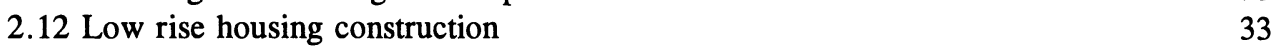

2.13 Case studies in low rise housing (foundations, external walls, roofs, floors) 35

2.14 Medium rise construction $\quad 51$

$\begin{array}{ll}2.15 \text { Case study in medium rise construction } & 60\end{array}$

3 The Construction Industry in France $\quad 69$

$\begin{array}{ll}3.1 \text { Key information } & 69\end{array}$

$\begin{array}{ll}3.2 \text { Construction output } & 69\end{array}$

$\begin{array}{ll}3.3 \text { Review of the construction industry } & 70\end{array}$

$\begin{array}{ll}3.4 \text { Extent of regionalisation (where applicable) } & 73\end{array}$

$\begin{array}{ll}3.5 \text { The housebuilding industry } & 73\end{array}$

3.6 Relationships within the construction industry $\quad 74$

3.7 Role of the architect $\quad 76$

$\begin{array}{ll}3.8 \text { Role of the engineer } & 77\end{array}$

$\begin{array}{ll}3.9 \text { Role of the quantity surveyor } & 78\end{array}$

3.10 Contractual arrangements and building procurement $\quad 79$

$\begin{array}{ll}3.11 \text { Planning and building control procedures } & 87\end{array}$

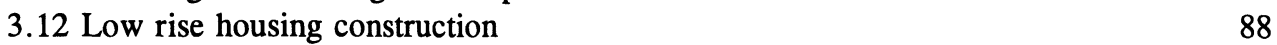

3.13 Case study in low rise housing (foundations, external walls, roofs, floors) 89

$\begin{array}{ll}3.14 \text { Medium rise construction } & 103\end{array}$

3.15 Case study in medium rise construction $\quad 106$

4 The Construction Industry in Germany 111

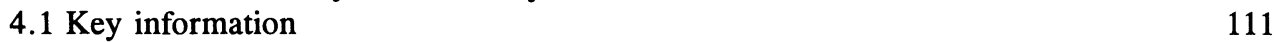

$\begin{array}{ll}4.2 \text { Construction output } & 111\end{array}$

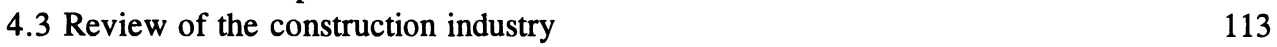

$\begin{array}{ll}4.4 \text { Extent of regionalisation } & 115\end{array}$

4.5 The housebuilding industry $\quad 115$

4.6 Relationships within the construction industry 119

$\begin{array}{ll}4.7 \text { Role of the architect } & 119\end{array}$ 
4.8 Role of the engineer $\quad 122$

$\begin{array}{ll}4.9 \text { Role of the quantity surveyor } & 124\end{array}$

4.10 Contractual arrangements and building procurement 125

4.11 Planning and building control procedures $\quad 130$

4.12 Low rise housing construction 133

4.13 Case studies in low rise housing (foundations, external walls, roofs, floors) 134

$\begin{array}{ll}4.14 \text { Medium rise housing construction } & 150\end{array}$

4.15 Case studies in medium rise housing construction $\quad 150$

5 The Construction Industry in The Netherlands $\quad 162$

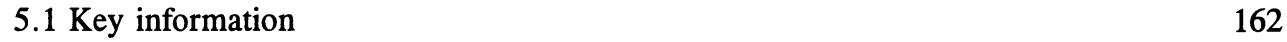

$\begin{array}{ll}5.2 \text { Construction output } & 162\end{array}$

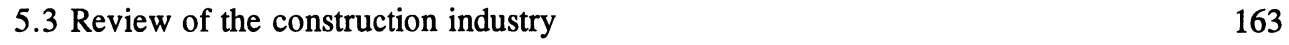

$\begin{array}{ll}5.4 \text { Extent of regionalisation } & 165\end{array}$

$\begin{array}{ll}5.5 \text { The housebuilding industry } & 167\end{array}$

$\begin{array}{ll}5.6 \text { Relationships within the construction industry } & 168\end{array}$

$\begin{array}{ll}5.7 \text { Role of the architect } & 168\end{array}$

$\begin{array}{ll}5.8 \text { Role of the engineer } & 172\end{array}$

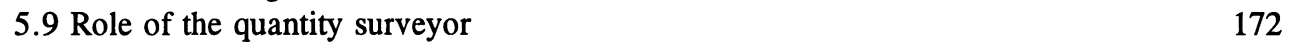

5.10 Contractual arrangements and building procurement $\quad 173$

$\begin{array}{ll}5.11 \text { Planning and building control procedures } & 173\end{array}$

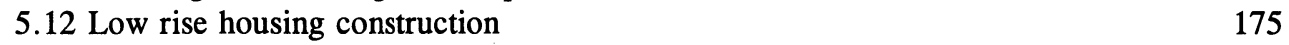

5.13 Case studies in low rise housing (foundations, external walls, roofs, floors) 179

$\begin{array}{ll}5.14 \text { Medium rise construction } & 205\end{array}$

5.15 Case studies in medium rise housing construction $\quad 209$

6 The Construction Industry in Portugal $\quad 218$

$\begin{array}{ll}6.1 \text { Key information } & 218\end{array}$

$\begin{array}{ll}6.2 \text { Construction output } & 218\end{array}$

$\begin{array}{ll}6.3 \text { Review of the construction industry } & 220\end{array}$

6.4 Extent of regionalisation (where applicable) $\quad 220$

$\begin{array}{ll}6.5 \text { The housebuilding industry } & 225\end{array}$

6.6 Relationships within the construction industry 226

$\begin{array}{ll}6.7 \text { Role of the architect } & 228\end{array}$

6.8 Role of the engineer $\quad 228$

6.9 Role of the quantity surveyor $\quad 229$

6.10 Contractual arrangements and building procurement 230

6.11 Planning and building control procedures $\quad 231$

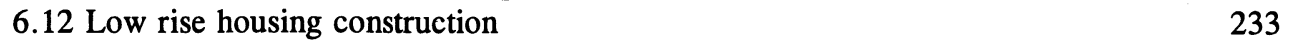

6.13 Case studies in low rise housing (foundations, external walls, roofs, floors) 234

6.14 Medium rise construction $\quad 243$

7 Comparative Data in the European Union $\quad 246$

8 References and bibliography $\quad 253$ 


\section{Preface}

On 1 January 1993 the Single European Market came into being. This, amongst other things, marked the end of trade barriers and a relaxation of customs regulations, enabling free movement within the European Union.

J. Bloggs Ltd can start work on a project in Paris, with their workers catching the 05.30 train from London to Paris. Is this fiction or reality? It could prove to be a nightmare experience for many contractors hoping to make a quick profit (or even a loss) by joining the European bandwagon. A lot of hard lessons will have to be learnt.

How then will the professional building contractor, consultant or student, face up to the challenge? What will they need to know about the practices, procedures and construction techniques in any one or more of the European countries?

These are the questions which have prompted us to write this book. How can we as lecturers (often defined as the gatherers and distributors of misinformation) prepare our students for the European experience?

The only way forward was to go, see and record what was happening in Europe. This we have done in order to produce the core content for this book, which is based on personal observations of construction projects in The Netherlands, Denmark, France, Germany and Portugal.

The objectives were specifically to highlight within each country aspects of construction practices and building methods utilised under the following headings:

Key information

Construction output

Review of the construction industry

Extent of regionalisation

The housebuilding industry

Relationships within the construction industry

The role of the Architect

The role of the Engineer

The role of the Quantity Surveyor

Contractual arrangements and building procurement

Planning and building control procedures

Low rise housing construction

Case studies on low rise housing projects

Medium rise construction

Case studies for medium rise construction

Within the text and diagrams an attempt has been made to bring out the differences in building from country to country. The construction details focus on the following building elements: foundations, external walls, floors and roof construction.

We hope that we have been successful in capturing the flavour of the countries visited.

B.C./G.W. April 1994 


\section{Acknowledgements}

The authors wish to thank the many project teams who have allowed access to building projects in Denmark, France, Germany, The Netherlands and Portugal.

Special thanks are due to G. Dellaert, J. Maleyran, Professor A.C. Toepfer, J. Taylor, and J.U. Wolff for their hospitality when visiting the various countries.

The authors also thank Paul Hodgkinson for his assistance in the production of the drawings and Peter Williams for help with the section on procurement in the Introduction.

Professor I.H. Seeley has once again allowed us the benefit of his expert advice on the book content and encouraged us throughout. We also wish to express our gratitude to the publishers for their continual assistance through the production of the book.

Finally, we wish to thank J. Gunning, G.H. Yeadon and A. Hollway for giving advice on text corrections.

\section{Lecturing materials available}

A series of slide packs and a CD-ROM are available to aid lecturers on the subject of European construction studies. Details obtainable from: Brian Cooke, 82 Torkington Road, Hazel Grove, Stockport SK7 4RL (Tel: 061483 6701) 